\title{
DETERMINANTS OF VISITOR EXPENDITURE AT THE TSITSIKamma National Park
}

\author{
Martinette Kruger* \\ North West University \\ Martinette.Kruger@nwu.ac.za \\ Melville Saayman\# \\ North West University \\ Melville.Saayman@nwu.ac.za \\ Bianca Manners+ \\ North West University \\ 20652445@nwu.ac.za
}

February 2012

\begin{abstract}
The Tsitsikamma National Park is Africa's oldest and largest marine reserve. It has considerable importance for the community and the region. In the face of declining government funding, it needs to attract more high spenders if it is to be sustainable. This requires an understanding of expenditure patterns and the determinants of Park visitors' spending behaviour. This study investigated the socio-demographic and behavioural determinants of visitor expenditure, using visitor surveys at the Park in 2010/2011. Correlation analysis and regression analysis established the most significant determinants. The results indicated that a longer stay, a smaller travel group and obtaining information from magazines were the variables associated with higher spending. These findings provide strategic insights for marketing the Park, with the aim of achieving a greater economic impact and competitive advantage and ultimately aiding conservation efforts.
\end{abstract}

\section{Keywords}

Tsitsikamma National Park, determinants of spending, marketing, nature-based tourism, tourist behaviour

\footnotetext{
*Dr Martinette Kruger is a senior lecturer at the Tourism Research Focus Area, TREES (Tourism Research in Economic Environs and Society) at the North West University, Potchefstroom, South Africa.

\#Prof Melville Saayman is professor at the Tourism Research Focus Area, TREદS (Tourism Research in Economic Environs and Society) at the North West University, Potchefstroom, South Africa.

+Miss Bianca Manners is a doctoral student at the Tourism Research Focus Area, TREES (Tourism Research in Economic Environs and Society) at the North West University, Potchefstroom, South Africa.
} 


\section{INTRODUCTION}

The Tsitsikamma National Park, situated in the impoverished Eastern Cape Province, is South Africa's oldest marine national park and one of the most popular (SANParks, 2010). National parks are powerful tourist magnets, major export earners and an important part of the tourism industry. They can contribute a significant proportion of the national GDP, foreign exchange earnings and employment figures. A 2009 study showed that this Park contributed over R21 million to the local economy and that approximately $46.7 \%$ of employment opportunities in the area resulted directly from the Park (Oberholzer, Saayman, Saayman \& Slabbert, 2009).

The problem facing South African National Parks (SANParks), and the Tsitsikamma National Park in particular is that parks have come to rely more heavily on tourist spending as a source of income since government grants have decreased (Wade \& Eagles, 2003). This means that the Park's managers and marketers have to identify the market that will provide the greatest return on investment (that is, the high-spending market), if they are to generate enough capital to continue to create a favourable tourist destination while at the same time conserving the natural environment (Tonge \& Moore, 2007). An increase in tourist spending has been shown to create a greater socio-economic impact in the region (WT0, 2002; Kastenholz, 2005; Legohérel \& Wong, 2006). Given the urgent needs of the Eastern Cape Province, this study therefore aimed to identify the high-spending tourists who visit the Park and the socio-demographic and behavioural variables that determine their spending behaviour.

\section{LITERATURE REVIEW}

According to Saayman and Saayman (1997) and Neuvonen, Pouta, Puustinen and Sievänen (2010), the economic impact of visitors at a destination such as the Tsitsikamma National Park is influenced by the magnitude of visitor spending, the number of visitors travelling to the destination, the type of destination (park) and the activities offered, the number of days spent in the area and the circulation (multiplier) of visitor spending through the economy of the area and community (as shown in FIGURE 1). Tourist spending is one of the most critical variables in analysing tourist destinations, since it directly determines the tourism sector's profitability (Frechtling, 2006). It is the first input in an economic impact assessment, so a true reflection of this spending and the factors that influence the amount that particular visitors spend is therefore an essential input in any economic impact study (Saayman, Saayman \& Du Plessis, 2005). It is important to identify which visitors spend most at a destination and which variables are most influential in determining their expenditure levels (Kastenholz, 2005). Once the factors that affect visitor expenditure have been determined, policies can be developed to strengthen the spending and maximise the economic benefits (Gokovali, Bahar \& Kozak, 2007). In the case of the Tsitsikamma National Park, when doing market segmentation the Park's management will be able to refer to the factors identified in the present study, so as to focus their marketing efforts on those visitors who spend the most at the Park (Kruger, 2009; Kruger, Saayman \& Saayman, 2011). 


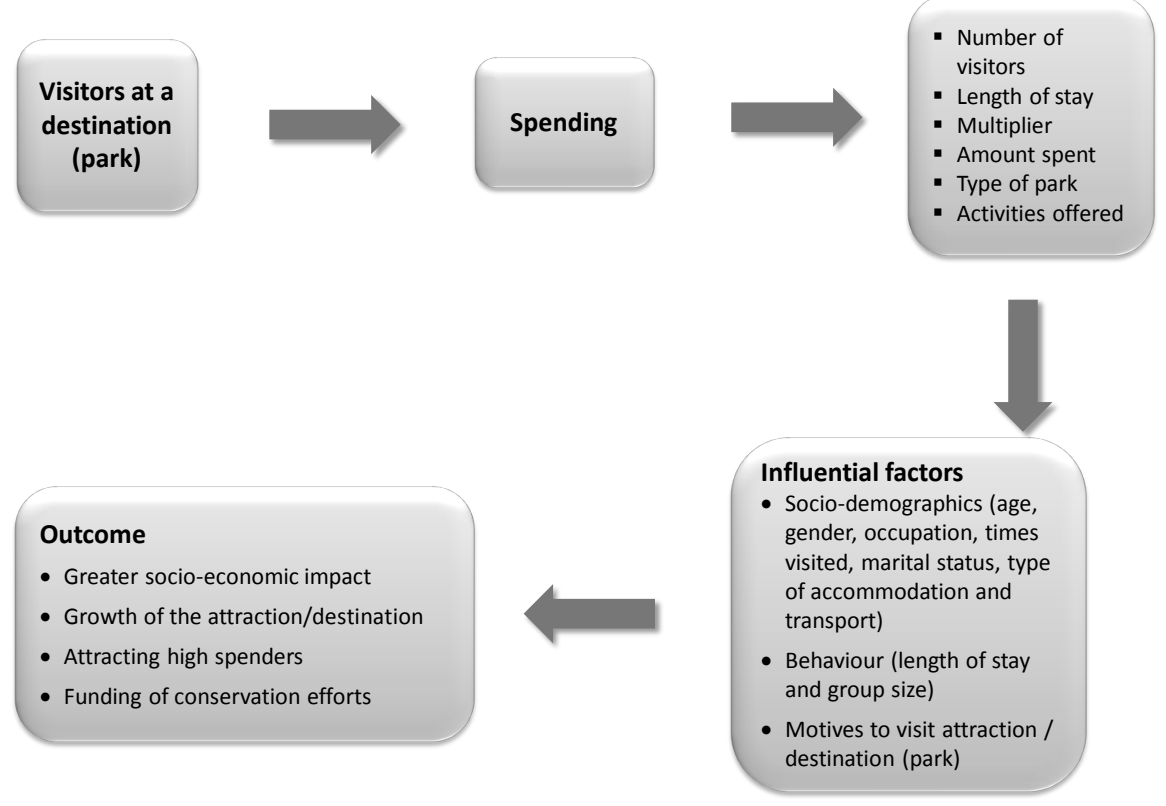

\section{FIGURE 1: Factors influencing visitor spending at a destination}

Source: Adapted from Saayman \& Saayman (1997), Craggs \& Schofield (2006) and Neuvonen et al. (2010)

Visitor expenditure is influenced by a wide range of socio-demographic and behavioural determinants. TABLE 1 provides a detailed summary of the most influential determinants of spending as indicated in the tourism literature. It is clear that previous research has seen individual visitor expenditure levels as being primarily influenced by socio-demographic variables. It is furthermore evident that the socio-demographic and behavioural determinants that influence visitor spending differ according to the particular tourism product, attraction or event. Spotts and Mahoney point out that travel expenditures for a given unit of travel activity vary significantly from one travel party to the next: travellers of different types may spend a vacation in the same area and at the same time yet spend their money in very different ways (1991). It can therefore be assumed that a variety of socio-demographic and behavioural determinants would influence the spending of visitors to the Park.

The literature provides a variety of findings specifically on the expenditure patterns of nature tourists. Leones, Colby and Crandall (1998) show that nature tourists spend more per party per trip than other visitors to the same area do, and that the number of local attractions visited, shorter trip duration and place of residence also have a positive effect on tourist spending. In their study of tourist expenditure to the North York Moors National Park in the UK, Downward and Lumsdon (2004) found that the mode of travel influenced spending patterns: car-borne visitors were likely to spend more per group and stay significantly longer than those using public transport such as buses. Pouta, Neuvonen and Sievänen (2006) studied the determinants of nature trip expenditures in southern Finland and found that increased visitor spending was related to trip characteristics such as higher income, first-time visits, longer distances travelled 
and longer stays. In a study of nature-based tourists to Northern Norway, Mehmetoglu (2007) found that travel activities were indeed a reliable predictor of tourist spending behaviour, that visitors who consider nature-based activities important tend to be high spenders, and that socio-demographic variables such as age, household income, length of stay and trip purpose were positively associated with higher daily expenditures.

\section{TABLE 1: Determinants of visitor spending}

\begin{tabular}{|c|c|c|}
\hline $\begin{array}{l}\text { Spending } \\
\text { determinant }\end{array}$ & Finding(s) & Author(s) \\
\hline Income & $\begin{array}{l}\text { Spending behaviour is positively associated } \\
\text { with higher household income. }\end{array}$ & $\begin{array}{l}\text { Mak, Moncur and Yonamine (1977), } \\
\text { Taylor, Fletcher and Clabaug } \\
\text { (1993),Crouch (1994), Fish and Waggle } \\
\text { (1996), Legohérel (1998), Cannon and } \\
\text { Ford (2002), Thrane (2002), } \\
\text { Mehmetoglu (2007), Kruger (2009), } \\
\text { Kruger et al. (2010) }\end{array}$ \\
\hline \multirow[t]{6}{*}{ Place of residence } & Visitors from out-of-state spend more. & Cannon \& Ford (2002) \\
\hline & $\begin{array}{l}\text { Province of origin (location) plays important } \\
\text { role in visitor spending at South African arts } \\
\text { festivals, national parks and sports events. } \\
\text { Visitors from richer provinces, e.g. Gauteng } \\
\text { and Western Cape, spend most. }\end{array}$ & $\begin{array}{l}\text { Saayman et al. (2007), Saayman and } \\
\text { Saayman (2008), Slabbert, Saayman, } \\
\text { Saayman and Viviers (2008), Kruger } \\
\text { (2009), Streicher and Saayman (2009) }\end{array}$ \\
\hline & $\begin{array}{l}\text { Spectators from the Western Cape spend less } \\
\text { than those from other provinces. }\end{array}$ & Kruger et al. (2011) \\
\hline & $\begin{array}{l}\text { In the Old Mutual Two Oceans Marathon, } \\
\text { South Africa, participants from Gauteng } \\
\text { spend more per person than those from the } \\
\text { Western Cape. }\end{array}$ & Saayman and Saayman (2011) \\
\hline & $\begin{array}{l}\text { In the Telkom Midmar Mile, South Africa, } \\
\text { swimmers from Gauteng spend more than } \\
\text { those from other provinces. }\end{array}$ & Saayman and Saayman (2011) \\
\hline & $\begin{array}{l}\text { Distance travelled to visit tourist } \\
\text { attractions affects expenditures positively. }\end{array}$ & $\begin{array}{l}\text { Long and Perdue (1990), Lee (2001), } \\
\text { Saayman et al. (2007) }\end{array}$ \\
\hline \multirow[t]{4}{*}{ Marital status } & $\begin{array}{l}\text { Effect of marital status on expenditure is } \\
\text { inconclusive. }\end{array}$ & Saayman et al. (2007) \\
\hline & $\begin{array}{l}\text { Married visitors stay fewer days and spend } \\
\text { significantly less per person per day than } \\
\text { unmarried. }\end{array}$ & Mak et al. (1977) \\
\hline & $\begin{array}{l}\text { Married swimmers participating in Telkom } \\
\text { Midmar Mile tend to spend less per person } \\
\text { than unmarried. }\end{array}$ & Saayman and Saayman (2011) \\
\hline & $\begin{array}{l}\text { Married cyclists participating in the Pick n } \\
\text { Pay Cape Argus Cycle Tour, South Africa, } \\
\text { spend more on average than unmarried. }\end{array}$ & Streicher and Saayman (2009) \\
\hline Level of education & $\begin{array}{l}\text { Visitors with a higher education level do not } \\
\text { stay significantly longer, and spend less per } \\
\text { day on average than less educated visitors. }\end{array}$ & $\begin{array}{l}\text { Mak et al. (1977), Gokovali et al. } \\
(2007)\end{array}$ \\
\hline
\end{tabular}




\begin{tabular}{|c|c|c|}
\hline $\begin{array}{l}\text { Spending } \\
\text { determinant }\end{array}$ & Finding(s) & Author(s) \\
\hline & $\begin{array}{l}\text { In the Pick n Pay Cape Argus Cycle Tour and } \\
\text { the Telkom Midmar Mile, participants with } \\
\text { postgraduate and professional education } \\
\text { spend significantly more than those with } \\
\text { only school education. }\end{array}$ & Saayman and Saayman (2011) \\
\hline \multirow[t]{2}{*}{$\begin{array}{l}\text { Children in travel } \\
\text { party }\end{array}$} & $\begin{array}{l}\text { Inclusion of children in travel party results in } \\
\text { decreased spending per day. }\end{array}$ & $\begin{array}{l}\text { Cai, Hong and Morrison (1995), Cannon } \\
\text { and Ford (2002), Saayman and } \\
\text { Saayman (2006) }\end{array}$ \\
\hline & $\begin{array}{l}\text { Presence of children has no significant } \\
\text { effect on expenditure. }\end{array}$ & Lee (2001) \\
\hline \multirow[t]{3}{*}{ Age } & Role of age is inconclusive. & $\begin{array}{l}\text { Cai et al. (1995), Lee (2001), Streicher } \\
\text { and Saayman (2009) }\end{array}$ \\
\hline & $\begin{array}{l}\text { A positive correlation was found between } \\
\text { age and total expenditure levels. }\end{array}$ & $\begin{array}{l}\text { Mak et al. (1977), Perez and Sampol } \\
(2000) \text {, Thrane (2002), Saayman and } \\
\text { Kastenholz (2005), Saayman (2006), } \\
\text { Saayman and Saayman (2011) }\end{array}$ \\
\hline & $\begin{array}{l}\text { Older visitors tend to spend less than } \\
\text { younger visitors. }\end{array}$ & $\begin{array}{l}\text { Mudambi and Baum (1997), Pouta et } \\
\text { al. (2006), Mehmetoglu (2007), Kruger } \\
\text { et al. (2010) }\end{array}$ \\
\hline \multirow[t]{2}{*}{ Gender } & Male visitors spend more than females. & $\begin{array}{l}\text { Thrane (2002), Kruger et al. (2011), } \\
\text { Saayman and Saayman (2011) }\end{array}$ \\
\hline & $\begin{array}{l}\text { Female visitors tend to spend more than } \\
\text { males. }\end{array}$ & $\begin{array}{l}\text { Letho, Cai, O'Leary and Huan (2004), } \\
\text { Craggs and Schofield (2006), Saayman } \\
\text { and Saayman (2011) }\end{array}$ \\
\hline Travel purpose & $\begin{array}{l}\text { Business travellers exhibit highest spending } \\
\text { patterns and most expensive travel style. }\end{array}$ & $\begin{array}{l}\text { Mok and Iverson (2000), Letho et al. } \\
(2004)\end{array}$ \\
\hline \multirow[t]{2}{*}{ Travel behaviour } & $\begin{array}{l}\text { Visitors who travel mainly to attend an arts } \\
\text { festival in South Africa spend more than } \\
\text { those who attend the festival for other } \\
\text { reasons. }\end{array}$ & $\begin{array}{l}\text { Thrane (2002), Kruger (2009), } \\
\text { Saayman et al. (2009), Kruger \& } \\
\text { Saayman (2009) }\end{array}$ \\
\hline & $\begin{array}{l}\text { Visitors who have attended other festivals in } \\
\text { South Africa are more likely to be high } \\
\text { spenders. }\end{array}$ & $\begin{array}{l}\text { Saayman \& Saayman (2006), Kruger } \\
(2009)\end{array}$ \\
\hline \multirow[t]{3}{*}{ Travel motives } & $\begin{array}{l}\text { Specific leisure travel motives (nature, } \\
\text { culture, sun, beach, etc.) or benefits sought } \\
\text { have rarely been studied and, generally, no } \\
\text { relevant impact on expenditure levels has } \\
\text { been found. }\end{array}$ & $\begin{array}{l}\text { Uysal, McDonald and Martin (1994), } \\
\text { Schneider and Backman (1996), } \\
\text { Downward and Lumsdon (2004), Lee et } \\
\text { al. (2004), De Guzman, Leones and } \\
\text { Tapia (2006), Beh and Bruyere (2007), } \\
\text { Saayman and Saayman (2008), Kruger } \\
\text { et al. (2009b) }\end{array}$ \\
\hline & $\begin{array}{l}\text { Tourists interested in culture tend to spend } \\
\text { more than other tourist groups. }\end{array}$ & Eusebio (2005) \\
\hline & $\begin{array}{l}\text { Participants in the Old Mutual Two Oceans } \\
\text { Marathon who are motivated to explore the } \\
\text { area tend to be higher spenders. }\end{array}$ & Saayman and Saayman (2011) \\
\hline
\end{tabular}




\begin{tabular}{|c|c|c|}
\hline $\begin{array}{l}\text { Spending } \\
\text { determinant }\end{array}$ & Finding(s) & Author(s) \\
\hline & $\begin{array}{l}\text { Cyclists in the Pick n Pay Cape Argus Cycle } \\
\text { Tour who attend the event as a family outing } \\
\text { or an opportunity to visit and tour the area } \\
\text { tend to spend more per person. }\end{array}$ & Saayman and Saayman (2011) \\
\hline & $\begin{array}{l}\text { Swimmers participating in the Telkom } \\
\text { Midmar Mile for personal motives such as } \\
\text { achievement tend to be higher spenders. }\end{array}$ & Saayman and Saayman (2011) \\
\hline \multirow[t]{2}{*}{ Group size } & $\begin{array}{l}\text { Larger group size is positively correlated } \\
\text { with overall expenditure levels. }\end{array}$ & $\begin{array}{l}\text { Lee (2001), Seiler, Seiler, Hsieh and } \\
\text { Hsieh (2002) }\end{array}$ \\
\hline & $\begin{array}{l}\text { An increase in the number of people in the } \\
\text { travel party leads to decrease in spending } \\
\text { per person. }\end{array}$ & $\begin{array}{l}\text { Saayman and Saayman (2008), } \\
\text { Saayman et al. (2009), Kruger et al. } \\
\text { (2011), Saayman and Saayman (2011) }\end{array}$ \\
\hline \multirow[t]{2}{*}{ Length of stay } & $\begin{array}{l}\text { Longer duration of stay is positively } \\
\text { correlated with overall expenditure levels. }\end{array}$ & $\begin{array}{l}\text { Seiler et al. (2002), Saayman, Krugell } \\
\text { and Van der Merwe (2007), Streicher } \\
\text { and Saayman (2009), Saayman and } \\
\text { Saayman (2011) }\end{array}$ \\
\hline & $\begin{array}{l}\text { Decreased spending per day is related to } \\
\text { longer duration of stay. }\end{array}$ & $\begin{array}{l}\text { Cannon and Ford (2002), Downward } \\
\text { and Lumsdon (2004), Sun and Stynes } \\
\text { (2006) Mehmetoglu (2007) }\end{array}$ \\
\hline \multirow[t]{2}{*}{$\begin{array}{l}\text { Preferred } \\
\text { accommodation }\end{array}$} & $\begin{array}{l}\text { Visitors with elaborate catering needs and } \\
\text { who prefer a combination of self-catering } \\
\text { and other types of catering tend to spend } \\
\text { more. }\end{array}$ & Saayman et al. (2007) \\
\hline & $\begin{array}{l}\text { Cyclists making use of paid accommodation } \\
\text { (e.g. hotels, bed \& breakfasts, guesthouses) } \\
\text { spend more. }\end{array}$ & Streicher and Saayman (2009) \\
\hline \multirow[t]{3}{*}{ Number of visits } & $\begin{array}{l}\text { Repeat visitors tend to spend more than first } \\
\text { time visitors. }\end{array}$ & $\begin{array}{l}\text { Gyte and Phelps (1989), Long and } \\
\text { Perdue (1990) }\end{array}$ \\
\hline & $\begin{array}{l}\text { Repeat visitors stay longer than first time } \\
\text { visitors, but do not spend significantly more } \\
\text { or less. }\end{array}$ & Mak et al. (1977) \\
\hline & $\begin{array}{l}\text { First time visitors spend more than repeat } \\
\text { visitors despite their shorter stay. }\end{array}$ & $\begin{array}{l}\text { Oppermann (1997), Jang, Bai, Hong } \\
\text { and O'Leary (2004), Petrick (2004), } \\
\text { Alegre and Juaneda (2006), Pouta et } \\
\text { al. (2006) }\end{array}$ \\
\hline Language & $\begin{array}{l}\text { English-speaking spectators at Old Mutual } \\
\text { Two Oceans Marathon and Pick n Pay Cage } \\
\text { Argus Cycle Tour tend to spend more than } \\
\text { Afrikaans-speaking visitors. }\end{array}$ & $\begin{array}{l}\text { Kruger et al. (2011), Saayman and } \\
\text { Saayman (2011) }\end{array}$ \\
\hline $\begin{array}{l}\text { Financial } \\
\text { responsibility (no. of } \\
\text { people paid for) }\end{array}$ & $\begin{array}{l}\text { Visitors who pay for fewer people at } \\
\text { Aardklop National Arts Festival, South } \\
\text { Africa, tend to spend more per person. }\end{array}$ & Kruger et al. (2010) \\
\hline
\end{tabular}

\section{Source: See author(s) listed}

Research specifically on South African national parks has mainly focused on segmenting visitors on the basis of their levels of expenditure. Saayman, Van der Merwe and Pienaar (2007) distinguish between high, medium and low spenders in their study of visitors to the Kruger 
National Park, South Africa. Visitors who stayed longer, travelled in a smaller group and who had travelled further to reach this park were likely to spend more. The findings of a segmentation study of visitors at the Tsitsikamma National Park by Kruger et al. (2010) were similar: visitors who stayed longer, travelled from Gauteng province, were financially responsible for fewer people and preferred to stay in chalets rather than camp were inclined to be higher spenders.

Building on the findings of the studies discussed above, the present study expects to contribute to the literature on the determinants of spending at national parks in South Africa. More practically, it aims to help Tsitsikamma National Park management to determine how the Park can attract more high spenders and also encourage more overall visitor expenditure - an important goal in the Eastern Cape Province, where unemployment is a severe problem (StatsSA, 2009) - and ultimately contribute to the sustainability of the Park.

\section{METHOD OF RESEARCH}

As this was quantitative research, a structured questionnaire was used to collect the data. This section describes the study area, the questionnaire, the sampling method and survey, and the statistical analysis.

\subsection{The study area}

The Tsitsikamma National Park is situated in the Eastern Cape Province of South Africa, in the heart of the picturesque tourist region known as the Garden Route. The Park stretches for $80 \mathrm{~km}$ from the Krom River Forest Station to the Salt River and lies between the Tsitsikamma Mountains and the coast (see FIGURE 2). In September 1964 the Park became the first marine national park to be proclaimed in Africa (SANParks, 2008). This Park protects a variety of inter-tidal and marine life forms, including many species of sea birds, and dolphins and the southern right whale (SANParks, 2008). Approximately $30 \%$ of the Park is covered in fynbos (Cape Floral Kingdom) and is considered one of the largest Marine Protected Areas in the world, conserving $11 \%$ of South Africa's Temperate South Coast rocky shoreline.

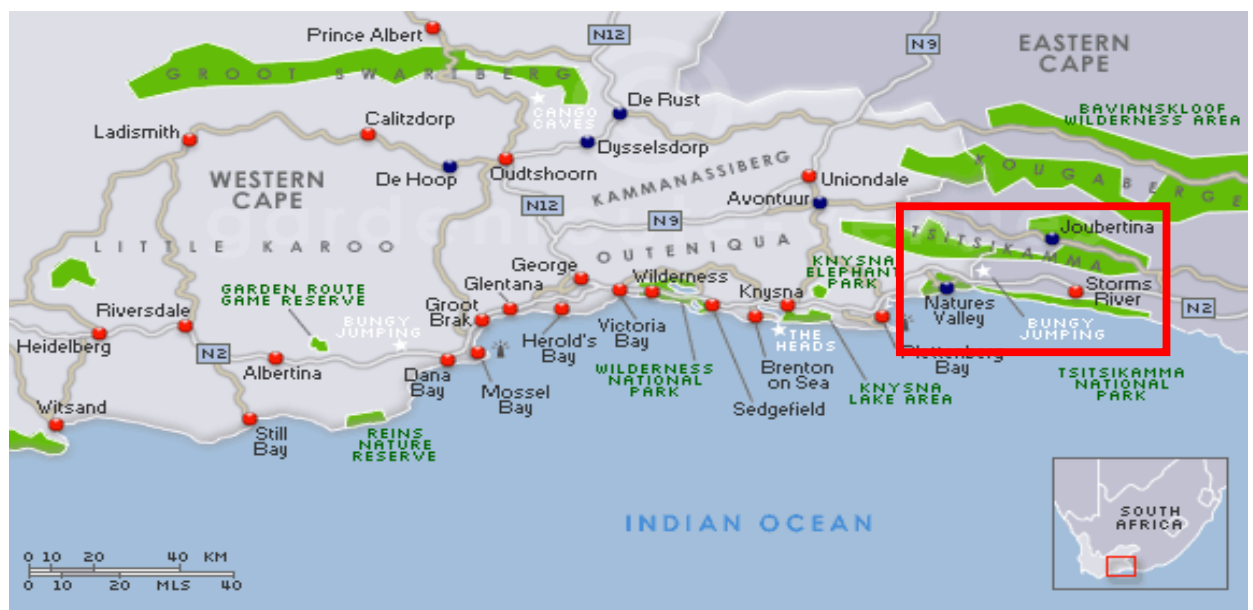

FIGURE 2: Location of Tsitsikamma National Park

Source: $\quad$ www.worldwide.co.za 
Among the Park's tourism attractions and activities, besides opportunities for appreciation of nature and photography, are hiking, backpacking, boating tours, swimming, picnicking, bungee jumping (the world's highest bungee jump is at Bloukrans), eating local foods such as seafood at the restaurant, and purchasing local arts and crafts (SANParks, 2008).

\subsection{The questionnaire}

The questionnaire used to survey visitors was based on similar research conducted by Leones et al. (1998), Downward and Lumsdon (2004), Mehmetoglu (2007), Saayman et al. (2007) and Kruger et al. (2010) and consisted of three sections. Section A captured the respondent's demographic details (language, gender, age, race, marital status, country of residence, province, highest qualification and occupation). Section B captured economic information such as size of travel group, number of people paid for, whether the respondent was visiting for the day or staying overnight, the type of accommodation used, the number of nights spent at the Park, the number of visits over the last three years, and spending dynamics. Section $C$ captured the respondent's reasons for visiting the Park. Twenty-three items were listed and respondents were asked to rate the importance of each item on a five-point Likert scale ( $1=$ not at all important, 2 = slightly important, 3 = important, 4 = very important, 5 = extremely important). For the purpose of this research, the information from all three sections was included in the analyses.

\subsection{Sampling method and survey}

The survey sample consisted of respondents to a questionnaire distributed to overnight visitors to the Park from 29 December 2010 to 3 January 2011. Field workers distributed questionnaires in the evenings and collected the questionnaires later during the same evening or early the next morning. SANParks statistics for 2009 were used to calculate the proportion of responses that would constitute a representative sample. Statistics show that the Park had approximately 50000 overnight visitors during 2009. Only one questionnaire was administered per travelling group. In 2009, and average of 3.16 visitors were financially sponsored per party (Kruger, Scholtz \& Saayman, 2009) which resulted in a sample size of approximately 15000 (50000 divided by 3.16). According to Israel (2009) a population of 15000 (N) will be sufficiently represented by 201 respondents (n) at a 7\% sampling error. In total, 250 questionnaires were administered and 225 completed questionnaires were included in the analysis. The number of completed questionnaires is thus greater than the number required.

\subsection{Statistical analysis}

Microsoft Excel was used to capture data and SPSS (SPSS Inc, 2010) for statistical analysis. The analyses were done in five stages. First, a general profile of the Park visitors in 2010/2011 was compiled. Second, a principal axis factor analysis, using an Oblimin rotation with Kaiser normalisation, was performed on the 23 motivation items to explain the variance-covariance structure of a set of variables through a few linear combinations of these variables. The KaiserMeyer-Olkin measure of sampling adequacy was also used to determine whether the covariance matrix was suitable for factor analysis. Kaiser's criteria for the extraction of all factors with eigenvalues larger than one were used because they were considered to explain a significant amount of variation in the data. In addition, all items with a factor loading above 0.3 were considered as contributing to a factor, and all with loadings lower than 0.3 as not correlating 
significantly with this factor (Steyn, 2000). In addition, any item that cross-loaded on two factors with factor loadings greater than 0.3 was categorised in the factor where interpretability was best. A reliability coefficient (Cronbach's alpha) was computed for each factor to estimate the internal consistency of each factor. All factors with a reliability coefficient above 0.6 were considered as acceptable in this study. The average inter-item correlations were also computed as a further measure of reliability - these, according to Clark and Watson (1995), should lie between 0.15 and 0.55 .

Third, the dependent (predicted) variable is spending per person, which was calculated by adding the respondent's spending on a variety of items listed such as conservation fee, accommodation, food, transport, activities and souvenirs. This gave total spending, which was then divided by the number of people the respondent was paying for, to give spending per person. The dummy variables (socio-demographic and behavioural variables) were coded $l$ and 0 to be included in the correlation and regression analyses. Fourth, correlation analysis and Spearmans Rank Order Correlation (rho) were used to explore the relationship between the dummy variables and the dependent variable (spending per person). According to Pallant (2010), a value of 0 indicates no relationship, 1.0 a perfect positive correlation, and -1.0 a perfect negative correlation. Cohen (1988) suggests the following guidelines to interpret the values between 0 and 1 : small effect: $r=.10$ to .29 , medium effect: $r=.30$ to .49 and a large effect: $r=.50$ to 1.0 .

Fifth, on the basis of the results of the correlation analysis, the best predictors for the dependent variable were selected and a linear regression analysis was done to identify the determinants of visitor spending at the Park. In the regression analysis, $R^{2}$ gives the proportion of variance in spending that is explained by the predictors included in the model. An $R^{2}$ of 0.25 or larger can be considered as practically significant ( $\varepsilon l l i s \&$ Steyn, 2003). The adjusted $R^{2}$ indicates how much variance in the outcome would be accounted for if the model had been derived from the population from which the sample was taken (Field, 2005). The adjusted $R^{2}$ therefore gives an idea of how well the regression model generalises and, ideally, its value needs to be the same as or very close to the value of $R^{2}$ (Field, 2005). The results from the statistical analyses are discussed in the next section.

\section{RESULTS}

This section provides an overview of the profile of the respondents (visitors to the Tsitsikamma National Park in 2010/2011), and presents the results of the factor analysis (travel motives), correlation analysis and linear regression analysis.

\subsection{Profile of respondents}

TABLE 2 shows that the majority of the 225 respondents surveyed at the Park from 29 December 2010 to 3 January 2011 were Afrikaans-speaking and married. Their average age was 46 . More than one third was travelling from either Gauteng or the Western Cape in a $4 \times 4$ vehicle. During their stay, respondents were financially responsible for an average of four persons, stayed an average of 11 nights and spent an average of R8 435.08 (approximately \$1 264) per trip. These visitors were loyal to the Park and had visited national parks an average of three times over the past three years. 
TABLE 2: Profile of Tsitsikamma National Park respondents $(n=225)$

\begin{tabular}{ll}
\multicolumn{1}{c}{ Category } & \multicolumn{1}{c}{ Profile } \\
\hline Home language & Afrikaans (70\%) \\
Age & On average, 46 years \\
Marital status & Married (89\%) \\
Province of residence & Gauteng (37\%) \& Western Cape (36\%) \\
Mode of transport & $4 \times 4(40 \%)$ \\
Number of visits to national parks over 3 years & 3 times on average \\
Average length of stay & 11.21 nights \\
Number of people paid for & Average of 3.54 \\
Average spending per trip & R8 435.08 \\
\hline Source: &
\end{tabular}

\subsection{Results of the factor analysis}

The pattern matrix of the principal axis factor analysis using an Oblimin rotation with Kaiser normalisation identified six motivational factors that were labelled according to similar characteristics (TABLE 3). These factors accounted for $69 \%$ of the total variance. All factors had relatively high reliability coefficients, ranging from 0.73 (the lowest) to 0.89 (the highest). The average inter-item correlation coefficients with values between 0.33 and 0.58 also implied internal consistency for all factors. Moreover, all items loaded on a factor with a loading greater than 0.3 and the relatively high factor loadings indicated a reasonably high correlation between the factors and their component items. The Kaiser-Meyer-Olkin measure of sampling adequacy of 0.84 also indicated that patterns of correlation were relatively compact and yielded distinct and reliable factors (Field, 2005). Barlett's test of sphericity also reached statistical significance $(p<.001)$, supporting the factorability of the correlation matrix (Pallant, 2007).

Factor scores were calculated as the average of all items, contributing to a specific factor in order to interpret them on the original five-point Likert scale of measurement. As TABLE 3 shows, the following reasons for visiting the Park were identified: Education (Factor 1), Park attributes and escape (Factor 2), Socialisation and family togetherness (Factor 3), Accommodation and Park attractiveness (Factor 4), Photography and exploration (Factor 5) and Proximity (Factor 6). With a mean value of 4.11, Park attributes and escape was found to be the most important motive, followed by Accommodation and Park attractiveness (3.89) and Socialisation and family togetherness (3.77). Photography and exploration (3.19) and Education (3.05) were rated as only moderately important. Proximity was rated the least important motive (1.91). 
TABLE 3: Results of factor analysis of Tsitsikamma National Park visitor motives

\begin{tabular}{|c|c|c|c|c|}
\hline Motivation factors and items & $\begin{array}{l}\text { Factor } \\
\text { loading }\end{array}$ & $\begin{array}{l}\text { Mean } \\
\text { value }\end{array}$ & $\begin{array}{l}\text { Reliability } \\
\text { coefficient }\end{array}$ & $\begin{array}{c}\text { Average } \\
\text { inter-item } \\
\text { correlation }\end{array}$ \\
\hline Factor 1 : Education & & 3.05 & 0.89 & 0.58 \\
\hline To learn about animals in general & 0.90 & & & \\
\hline To learn about endangered species & 0.90 & & & \\
\hline $\begin{array}{l}\text { Primarily for educational reasons (to learn things, increase } \\
\text { my knowledge) }\end{array}$ & 0.78 & & & \\
\hline $\begin{array}{l}\text { So that members in my party could develop an appreciation } \\
\text { for endangered species and wildlife }\end{array}$ & 0.76 & & & \\
\hline To learn about specific marine animals & 0.74 & & & \\
\hline So that other members in my party could learn about nature & 0.63 & & & \\
\hline To watch whales and dolphins & 0.40 & & & \\
\hline Factor 2: Park attributes and escape & & 4.11 & 0.73 & 0.39 \\
\hline Primarily to experience the scenic beauty of the Park & 0.85 & & & \\
\hline I prefer the Park for its geographical features & 0.68 & & & \\
\hline To get away from my routine & 0.47 & & & \\
\hline To relax & 0.43 & & & \\
\hline To do hiking trails & 0.39 & & & \\
\hline Factor 3: Socialisation and family togetherness & & 3.77 & 0.58 & 0.33 \\
\hline To be with family or to spend time with someone special & 0.44 & & & \\
\hline To spend time with my friends & 0.40 & & & \\
\hline For the benefit of my children & 0.36 & & & \\
\hline Factor 4: Accommodation and Park attractiveness & & 3.89 & 0.79 & 0.49 \\
\hline The Park has great accommodation facilities & 086. & & & \\
\hline The Park has a variety of accommodation to choose from & 0.75 & & & \\
\hline It is value for money & 0.57 & & & \\
\hline It is the ideal holiday destination & 0.35 & & & \\
\hline Factor 5: Photography and exploration & & 3.19 & 0.62 & 0.35 \\
\hline For photographic reasons & 0.86 & & & \\
\hline To explore an new destination & 0.40 & & & \\
\hline It is a spiritual experience & 0.28 & & & \\
\hline Factor 6: Proximity & & 1.91 & & \\
\hline It is the nearest park for me & 0.41 & & & \\
\hline Total variance explained & $69 \%$ & & & \\
\hline
\end{tabular}

Source: Results from statistical analysis

\subsubsection{Results of the correlation analysis and Spearman's rho}

Most questions offered multiple choice responses or choices on a 5-point Likert scale and the dummy variables were coded 1 and 0 as shown in TABLE 4 . The relationship between the variables shown in TABLE 4 and spending per person was investigated by using Spearman's Rank Order Correlation (rho). The following variables had a small to medium relationship with spending per 
person for the survey respondents.

- Socio-demographics and behavioural variables: Home language, age, mode of transport, times visited and being a holder of a Wild Card (loyalty card which generates income for conservation efforts in the Park) had a small, positive correlation with spending per person, indicating that older, Afrikaans-speaking visitors who travelled to the Park with a $4 \times 4$, those who had visited the Park more often and those who were Wild Card holders, tended to spend more at the Park. Being from the Western Cape and paying for a larger number of people had a small, negative correlation, showing that visitors from this province and those who were financially responsible for more people were likely to spend less. Number of nights spent and being from Gauteng had a medium, positive correlation, indicating that visitors from this province and those who stayed longer tended to spend more.

- Media preferences: SANParks' website, friends and family, magazines and talks at the visitor centre by SANParks all had a small, positive correlation with spending per person, indicating that visitors who had heard about the Park through these sources were inclined to spend more. The opposite was true for visitors who relied on their previous visits, since this had a small, negative correlation.

- Catering preferences: Visitors at the Park who preferred self-catering accommodation (small, negative correlation) tend to be lower spenders than those who preferred to dine out and use self-catering accommodation (small, positive correlation).

- Travel motives: There was a small, positive correlation between the travel motives Education, Park attributes and Escape and Photography and exploration, indicating that visitors who were motivated more by these factors were inclined to be higher spenders. The travel motives Socialisation and family togetherness, Accommodation and Park attractiveness and Proximity had a small, negative correlation with spending per person, showing that visitors who visited the Park for these reasons tended to spend less.

- Preferred services at the visitor centre: The small, positive correlations of all four services at the visitor centre (auditorium, slide shows, specialist talks and entertainment for children) indicate that visitors who prefer these services tended to spend more.

- Preferred recreation activities for children: Educational talks, guided walks, parent and child activities and marine activities had a small, positive correlation with spending per person, showing that visitors who preferred these activities were inclined to spend more. Activities, games and recreational programmes had a small, negative correlation, however, showing that visitors who preferred these activities tended to spend less.

TABLE 4: Relationship between variables and respondents' spending tendencies

\begin{tabular}{|c|c|c|c|}
\hline Category & Variable (topic of question) & Coding & Spearman's rho** \\
\hline \multirow{4}{*}{$\begin{array}{l}\text { Socio- } \\
\text { demographics }\end{array}$} & LANGUAGE & $A f r=1, \varepsilon n g=0$ & \multirow{4}{*}{$\begin{array}{l}\text { rho }=.17, \mathrm{n}=206, p= \\
.015^{\star}, \mathrm{rho}=.03, \mathrm{n}=207, \\
p=.657, \mathrm{rho}=.25, \\
\mathrm{n}=208, p=.001^{*}, \mathrm{rho}=- \\
.18, \mathrm{n}=208, p=.009 *\end{array}$} \\
\hline & $A G \varepsilon$ & Open question & \\
\hline & GAUTENG & Yes $=1$, No $=0$ & \\
\hline & WESTERN CAPE & $y_{e s}=1, N_{o}=0$ & \\
\hline \multirow[t]{4}{*}{ Behavioural } & PEOPLE PAID FOR & Open question & \multirow{4}{*}{$\begin{array}{l}\text { rho }=-.23, \mathrm{n}=207, p= \\
.001^{*} \text { rho }=.36, \mathrm{n}=211 \\
p=.001 * \text { rho }=.10 \\
\mathrm{n}=212, p=.133 \\
\text { rho }=.02, \mathrm{n}=205, p=\end{array}$} \\
\hline & NIGHTS & Open question & \\
\hline & TIMES & Open question & \\
\hline & TRANSPORT & $4 \times 4=1,0$ ther $=0$ & \\
\hline
\end{tabular}




\begin{tabular}{|c|c|c|c|}
\hline Category & Variable (topic of question) & Coding & Spearman's rho** \\
\hline & WILD CARD HOLDER & Yes $=1$, No $=0$ & $\begin{array}{l}.820 \text { rho }=.22, \mathrm{n}=209, p \\
=.002^{\star}\end{array}$ \\
\hline \multirow{5}{*}{$\begin{array}{l}\text { Media } \\
\text { preferences }\end{array}$} & WEBSITE & Yes $=1$, No $=0$ & \multirow{5}{*}{$\begin{array}{l}\text { rho }=.09, \mathrm{n}=211, p= \\
.179 \text { rho }=.15, \mathrm{n}=210, p \\
=.034^{\star} \text { rho }=.17, \\
\mathrm{n}=210, p=.013^{\star} \\
\text { rho }=.08, \mathrm{n}=211, p= \\
.226 \text { rho }=-.13, \mathrm{n}=211, \\
p=.056\end{array}$} \\
\hline & WORD OF MOUTH & Yes $=1$, No $=0$ & \\
\hline & MAGAZINES & Yes $=1$, No $=0$ & \\
\hline & SANPARKS & $y_{e s}=1$, No $=0$ & \\
\hline & PREVIOUS VISITS & Yes $=1, N_{0}=0$ & \\
\hline \multirow{2}{*}{$\begin{array}{l}\text { Catering } \\
\text { preferences }\end{array}$} & SELF-CATERING & Yes $=1$, No $=0$ & \multirow{2}{*}{$\begin{array}{l}\text { rho }=-.00, \mathrm{n}=210, p \\
.960 \text { rho }=.11, \mathrm{n}=210, p \\
=.101\end{array}$} \\
\hline & DINE OUT\&SELF-CATERING & Yes $=1, N_{o}=0$ & \\
\hline \multirow[t]{6}{*}{ Travel motives } & EDUCATION & 5-point Likert scale & \multirow{6}{*}{$\begin{array}{l}\text { rho }=.05, \mathrm{n}=208, p= \\
.456 \text { rho }=.01, \mathrm{n}=210, p \\
=.884 \text { rho }=-.03, \mathrm{n}=208, \\
p=.695 \text { rho }=-.02, \\
\mathrm{n}=209, p=.791 \\
\text { rho }=.04, \mathrm{n}=208, p= \\
.599 \text { rho }=-.05, \mathrm{n}=203, \\
p=.479\end{array}$} \\
\hline & PARK ATTRIBUTES\&ESCAPE & 5-point Likert scale & \\
\hline & SOCIALISATION\&FAMILY & 5-point Likert scale & \\
\hline & ACCOMMODATION\&PARK & 5-point Likert scale & \\
\hline & PHOTOGRAPHY\&EXPLORATION & 5-point Likert scale & \\
\hline & PROXIMITY & 5-point Likert scale & \\
\hline \multirow{4}{*}{$\begin{array}{l}\text { Preferred } \\
\text { services at Park } \\
\text { visitor centre }\end{array}$} & AUDITORIUM & Yes $=1$, No $=0$ & \multirow{4}{*}{$\begin{array}{l}\text { rho }=.11, \mathrm{n}=203, p= \\
.108 \text { rho }=.13, \mathrm{n}=203, p \\
=.062 \text { rho }=.17, \mathrm{n}=203, \\
p=.015^{\star} \text { rho }=.06, \\
\mathrm{n}=203, p=.379\end{array}$} \\
\hline & SLIDE SHOWS & $y_{e s}=1, N_{0}=0$ & \\
\hline & SPECIALIST TALKS & Yes $=1, N_{0}=0$ & \\
\hline & CHILD ENTERTAINMENT & Yes $=1$, No $_{0} 0$ & \\
\hline \multirow{6}{*}{$\begin{array}{l}\text { Preferred } \\
\text { recreation } \\
\text { activities for } \\
\text { children }\end{array}$} & GAMES & $y_{e s}=1$, No $=0$ & \multirow{6}{*}{$\begin{array}{l}\text { rho }=-.01, \mathrm{n}=161, p= \\
.938 \mathrm{rho}=.01, \mathrm{n}=161, p \\
=.889 \text { rho }=.12, \mathrm{n}=161, \\
p=.131 \text { rho }=.08, \\
\mathrm{n}=161, p=.313 \text { rho }=- \\
.01, \mathrm{n}=161, p=.901 \\
\text { rho }=.14, \mathrm{n}=161, p= \\
.088\end{array}$} \\
\hline & EDUCATIONAL TALKS & $y_{\text {es }}=1$, No $_{0}=0$ & \\
\hline & GUIDED WALKS & $y_{e s}=1, N_{o}=0$ & \\
\hline & PARENT\&CHILD ACTIVITIES & $y_{e s}=1, N_{o}=0$ & \\
\hline & RECREATIONAL PROGRAMMES & Yes $=1$, No $=0$ & \\
\hline & MARINE ACTIVITIES & Yes $=1$, No $=0$ & \\
\hline
\end{tabular}

\section{Source: Results from statistical analysis}

$\star \star$ Rho interpretation: $.10=$ small effect, $.30=$ medium effect, $.50=$ large effect. $*$ Significance level $p=.05$

\subsubsection{Results of the linear regression analysis}

A linear regression was performed to assess the impact of some of the variables from TABLE 4 on the likelihood that Park visitors' spending per person would increase. These were the independent variables that were dummy coded as $l$ and 0 and that correlated most strongly with spending per person: language, coming from Gauteng province, coming from the Western Cape province, number of people paid for, number of nights stayed, recommendations from family and friends, getting information from magazines and from specialist talks and being a Wild Card holder (see TABLE 5).

These variables explained $16 \%$ (adjusted $R^{2}$ ) of the variance in spending per person, $F(9,187)=$ $5.086, p=.001$. The significant results are discussed below. 
TABLE 5: Regression analysis results: Spending per person

\begin{tabular}{|c|c|c|c|c|c|}
\hline \multirow[t]{2}{*}{ Model } & \multicolumn{2}{|c|}{$\begin{array}{c}\text { Unstandardised } \\
\text { coefficients }\end{array}$} & \multirow{2}{*}{$\begin{array}{c}\text { Standardised } \\
\text { coefficients } \\
\text { Beta }\end{array}$} & \multirow[t]{2}{*}{$t$} & \multirow[t]{2}{*}{ Sig. } \\
\hline & $B$ & Std. error & & & \\
\hline (Constant) & 2089.520 & 854.409 & & 2.446 & .015 \\
\hline LANGUAGE & 719.091 & 503.706 & .099 & 1.428 & .155 \\
\hline GAUTENG & 1142.106 & 595.518 & .169 & 1.918 & .057 \\
\hline WESTERN CAPE & -52.444 & 578.242 & -.008 & -.091 & .928 \\
\hline PEOPLE PAID FOR & -485.742 & 158.025 & -.217 & -3.074 & .002 \\
\hline NIGHTS & 106.743 & 32.488 & .260 & 3.286 & .001 \\
\hline WORD OF MOUTH & 440.475 & 459.556 & .068 & .958 & .339 \\
\hline MAGAZINES & 1238.511 & 542.913 & .163 & 2.281 & .024 \\
\hline SPECIALIST TALKS & -491.052 & 474.976 & -.075 & -1.034 & .303 \\
\hline WILD CARD HOLDER & -100.382 & 735.243 & -.010 & -.137 & .892 \\
\hline $\mathrm{R}$ & 0.45 & & & $F(9,187)$ & 5.09 \\
\hline $\mathrm{R}^{2}$ & 0.21 & & & & \\
\hline Adjusted $\mathrm{R}^{2}$ & 0.16 & & Std. error of esti & & 2978.63 \\
\hline
\end{tabular}

Source: Results from statistical analysis

The results in TABLE 5 show that people paid for $(p=.002)$, nights $(p=.001)$ and magazines $(p=$ .024) had a statistically significant influence on higher spending. From the signs of the coefficients it is clear that the respondents who were financially responsible for fewer people, who stay more nights in the Park and who had heard about the Park through magazines tended to spend more. Even though the other variables were not statistically significant, it can be seen from the signs of the coefficients that respondents from Gauteng tended to spend more than those from the Western Cape. Respondents who had heard about the Park from family and friends (word of mouth) tended to spend more than respondents who had received their information from specialist talks at the visitor centre and also more than respondents who were Wild Card holders.

\section{FINDINGS AND IMPLICATIONS}

The purpose of this study was to establish the determinants of spending by visitors to the Tsitsikamma National Park. The results corroborate the findings by Spotts and Mahoney (1991) and Craggs and Schofield (2006) that a variety of socio-demographic and behavioural determinants influences visitor expenditure and that these determinants vary from one travel party and destination to the next. However, the results reversed those of previous research (as discussed in the literature review and outlined in TABLE $\mathbf{l}$ ) in finding that visitor expenditure was influenced more by behavioural (length of stay, group size and magazines as preferred source of information) than socio-demographic variables. The following behavioural variables were statistically influential: 
- Corroborating a finding of research by Saayman and Saayman (2001), Seiler et al. (2002), Pouta et al. (2006), Saayman et al. (2007), Streicher and Saayman (2009) and Kruger et al. (2010), length of stay had a significant influence on visitor spending. Respondents who stayed more nights at the Park tended to be higher spenders, perhaps because of extra opportunity to take advantage of the variety of activities on offer. However, this contradicts the finding by Leones et al. (1998), Cannon and Ford (2002), Downward and Lumsdon (2004), Sun and Stynes (2006) and Mehmetoglu (2007) that a longer stay meant less spending.

- Higher spending at the Park was also found to be associated with fewer people in the travelling group, which is consistent with the findings by Saayman et al. (2007), Saayman and Saayman (2008), Saayman et al. (2009), Kruger et al. (2010) and Saayman and Saayman (2011) that an increase in the number of people in the travel party led to a decrease in spending. An explanation for this could be that larger groups share the costs, which makes the trip cheaper per person. However, this contradicts the finding by Lee (2001) and Seiler et al. (2002) that a larger group size means higher spending.

- Visitors who furthermore made use of magazines to obtain information about the Park also tend to spend more. Compared to the previous research findings discussed in the literature review, this was the first time that a marketing medium positively correlates with higher spending at a tourism destination.

Although the variables discussed below correlated with spending per person, the results of the regression analysis indicated that they had no additional influence on higher spending. However, these variables should not be excluded when interpreting the overall findings of the regression analysis.

- Respondents from Gauteng province (in other words visitors who travelled further to get to the Park) spent more than those from the Western Cape. Saayman et al. (2007), Saayman and Saayman (2008), Slabbert et al. (2008), Kruger (2009), Kruger et al. (2010), and Saayman and Saayman (2011) also found that visitors from the more affluent provinces in South Africa, especially Gauteng, tended to spend more.

- Afrikaans-speaking respondents were found to be inclined to spend more at the Park than English-speaking respondents. This contradicts the findings by Kruger et al. (2010) and Saayman and Saayman (2011) that English-speaking visitors were inclined to be higher spenders.

Some significant marketing and management implications may be drawn from these findings. To attract more high spenders to the Park, Gauteng Province should obviously be targeted. The highest-rated motives for visiting the Park were Park attributes and escape and Accommodation and Park attractiveness, followed by Socialisation and family togetherness and Photography and exploration, so a marketing campaign aimed at attracting the target market would do well to incorporate these travel motives. Since length of stay appears to have a positive impact on spending, management should investigate ways of encouraging visitors to stay longer at the Park. They could consider providing further activities, taking into consideration research findings about the kind of activities visitors prefer and looking at ways to market the activities so as to bring them to the attention of potential visitors. Since photography was found to be a strong reason for visiting the Park, by offering photographic competitions and exhibitions management could attract amateur and professional photographers to the Park and encourage them to stay longer. By cooperating with other tourism product and service providers management could expand the marketing of attractions in the area, thus providing further 
reason for Park visitors to stay longer. Packages aimed at the high expenditure segment could be a particularly effective way of increasing the length of stay as well as overall spending at the Park. When it comes to advertising the Park, since high spenders' main source of information was found to be magazines, full advantage should be taken of this medium. This could ensure costeffective advertising aimed at the desired target market, the higher spenders, and it could reach visitors who have not yet visited the Park. Further research should be conducted to ascertain which magazines are being read by the target market, to provide more direct and personalised marketing.

\section{CONCLUSION}

Since only minimal research has so far been done into the determinants of spending at national parks, and since the findings have varied from one park to the next, there is a clear need for more research of this kind. The drive to increase spending at the national parks should be seen against the background of a decline in government funding for conservation and ever-growing conservation needs. This aim of this research into park visitors' spending tendencies and ways to attract high spenders is ultimately to maintain and grow conservation efforts. From an environmental point of view, it is better to have 10 visitors spending R100 than 100 visitors spending R10. This study therefore contributes to the discourse on how tourism contributes to conservation, since conservation depends to a large extent on the income from tourism, and it also makes practical recommendations. The small number of similar studies means that a limitation of this study is the lack of material for comparing findings. For a better understanding of visitor spending behaviour, it is recommended that this research be broadened to other parks and natural attractions, since it appears that the type of park and the activities offered play a significant role in visitor spending. Further, the fact that magazines were for the first time identified as a determinant warrants more research on the effect that marketing media and sources of information have on expenditure levels.

\section{Acknowledgement}

The authors gratefully acknowledge the South African National Parks (SANParks) for their financial support for this project. The authors would also like to thank all the fieldworkers and respondents who participated in the survey.

\section{LIST OF REFERENCES}

Alegre, J. \& Juaneda, C. (2006). Destination loyalty consumers' economic behaviour. Annals of Tourism Research, 33(3), pp. 684-706.

Cai, L.A., Hong, G. \& Morrison, A.M. (1995). Household expenditure patterns for tourism products and services. Journal of Travel and Tourism Marketing, 4(4), pp. 15-40.

Clark, L.A. \& Watson, D. (1995). Constructing validity: Basic issues in objective scale development. Psychological Assessment, 7(3), pp. 309-319.

Craggs, R. \& Schofield, P. (2006). Expenditure segmentation and visitor profiling: Regenerating the Quays in Salford, UK. University of Northumberland, University of Salford. 
Crouch, G.J. (1994). The study of international tourism demand: A review of findings. Journal of Travel Research, 33(1), pp. 12-23.

De Guzman, A.B., Leones, J.D., Tapia, K.K.L., Wong, W.G. \& De Castro, B.V. (2006). Segmenting motivation. Annals of Tourism Research, 33(3), pp. 863-867.

Downward, P. \& Lumsdon, L. (2004). Tourism transport and visitor spending: A study in the North York Moors National Park, UK. Journal of Travel Research, 42(4), pp. 415-420.

Ellis, S.M. \& Steyn, H.S. (2003). Practical significance (effect sizes) versus or in combination with statistical significance ( $p$ values). Management dynamics, 12(1), pp. 51-53.

Faasen, H. (2006). Synergies between biodiversity conservation and sustainable rural development of adjacent communities: A case study of the Tsitsikamma National Park. Stellenbosch: University of Stellenbosch. (Thesis - Master of Science in conservation ecology)

Field, A. (2005). Discovering statistics using SPSS, $2^{\text {nd }}$ ed. London; Thousand Oaks: Sage.

Fish, M. \& Waggle, D. (1996). Current income versus total expenditure measures in regression models of vacation and pleasure travel. Journal of Travel Research, 35(2), pp. 70-74.

Frechtling, D.C. (2006). An assessment of visitor expenditure methods and models. Journal of Travel Research, 20, pp. 1-10.

Gokovali, U., Bahar, 0. \& Kozak, M. (2007). Determinants of length of stay: A practical use of survival analysis. Tourism Management, 28, pp. 736-746.

Gyte, D.M. \& Phelps, A. (1989). Patterns of destination repeat business: British tourists in Mallorca, Spain. Journal of Travel Research, 28(1), pp. 24-28.

Jang, S., Bai, B., Hong, G. \& O'Leary, J.T. (2004). Understanding travel expenditure patterns: A study of Japanese pleasure travellers to the United States by income level. Tourism Management, 25(3), pp. 331-341.

Kastenholz, દ. (2005). Analysing determinants of visitor spending for the rural tourist market in North Portugal. Tourism Economics, 11 (4), pp. 555-569.

Kruger, M. (2009), Spending behaviour of visitors to the Klein Karoo National Arts Festival. Master's Thesis, North West University, Potchefstroom.

Lee, H. (2001). Determinants of recreational boater expenditures on trips. Tourism Management, 22, pp. 659-667.

Legohérel, P. \& Wong, K.F. (2006). Market segmentation in the tourism industry and consumers' spending. Journal of Travel and Tourism Marketing, 20(2), pp. 15-30.

Leones, J., Colby, B. \& Crandall, K. (1998). Tracking expenditures of the elusive nature tourists to south-eastern Arizona. Journal of Travel Research, 36, pp. 56-64.

Letho, X.Y., Cai, L.A., O'Leary, J.T. \& Huan, T. (2004). Tourist shopping preferences and expenditure behaviours: The case of the Taiwanese outbound market. Journal of Vacation Marketing, 10(4), pp. 320-332.

Long, P.T. \& Perdue, R.R. (1990). The economic impact of rural festivals and special events: Assessing the spatial distribution of expenditures. Journal of Travel Research, 39(4), pp. 10-14.

Mak, J., Moncur, J. \& Yonamine, D. (1977). Determinants of visitors expenditures and visitor lengths of stay: A cross-section analysis of U.S. visitors to Hawaii. Journal of Travel Research, 15(3), pp. 5-8. 
Mehmetoglu, M. (2007). Nature-based tourists: The relationship between their trip expenditures and activities. Journal of Sustainable Tourism, 15(2), pp. 200-215.

Mudambi, R. \& Baum, T. (1997). Strategic segmentation: An empirical analysis of tourist expenditure in Turkey. Journal of Travel Research, 36(1), pp. 29-34.

Oberholzer, S., Saayman, M., Saayman, A. \& Slabbert, દ. (2009). The socio-economic impact of Africa's oldest marine park. Part of the $6^{\text {th }}$ International Congress on Coastal and Marine Tourism conference proceedings held on 23-26 June 2009, Nelson Mandela Bay, South Africa. pp. 181-196.

Oppermann, M. (1997). First-time and repeat tourists to New Zealand. Tourism management, 18(3), pp. 177-181.

Pallant, J. (2007). SPSS Survival manual: A step-by-step guide to data analysis using SPSS version 15, $\zeta^{\text {td }}$ edition. New York: McGraw-Hill.

Pallant, J. (2010), SPSS Survival manual: A step-by-step guide to data analysis using SPSS version 16, $4^{\text {th }}$ edition. New York: McGraw-Hill.

Perez, E.A. \& Sampol, J.C. (2000). Tourist expenditure for mass tourism markets. Annals of Tourism Research, 27(3), pp. 624-637.

Petrick, J.F. (2004). Are loyal visitor the desired visitors? Tourism Management, 25(4), pp. 463-470.

Pouta, $\varepsilon$., Neuvonen, M., \& Sievänen, T. (2006). Determinants of nature trip expenditures in Southern Finland - Implications for nature tourism development. Scandinavian Journal of Hospitality and Tourism, 6(2), pp. 118-135.

Saayman, A. \& Saayman, M. (2006). Socio-demographics and visiting patterns of arts festivals in South Africa. Event Management, 9(4), pp. 211-222.

Saayman, A. \& Saayman, M. (2008). Socio-Demographic and Behavioural Determinants of Visitor Spending at the Kruger National Park in South Africa. (In process of review).

Saayman, M., Krugell, W. \& Van Der Merwe, P. (2007). The determinants of spending by biltong hunters. South African Journal of Economics and Management Science, 10(2), pp. 184-194.

Saayman, M., Saayman, A. \& Du Plessis, C. (2005). Analysis of spending patterns of visitors of three World Cup Cricket matches in Potchefstroom, South Africa. Journal of Sport Tourism, 10(3), pp. 211 221.

Saayman, M., Van Der Merwe, P. \& Pienaar, J. (2007). Expenditure-based segmentation of tourists to the Kruger National Park. First conference of the international associations of tourism economics, 25-27 October 2007, Palma de Mallorca, Spain.

Schneider, I.E. \& Backman, S.J. (1996). Cross-cultural equivalence of festival motivations: A study in Jordan. Festival Management and Event Tourism, 4(3/4), pp. 139-144.

Seiler, V.L., Seiler, M.J., Hsieh, C. \& Hsieh, S. (2002). Modeling travel expenditures for Taiwanese tourism. Journal of Travel and Tourism Marketing, 13(4), pp. 47-59.

Slabbert, E., Saayman, M., Saayman, A. \& Viviers, P. (2008). Die sosio-ekonomiese impak van besoekers aan die ABSA KKNK. Potchefstroom: Instituut vir Toerisme en Vryetydstudies.

Spotts, D.M. \& Mahoney, E.M. (1991). Segmenting visitors to a destination region based on the volume of their expenditures. Business Research Division, 29(4), pp. 42-31.

Statistics South Africa see StatsSA 
StatsSA. (2009). Quarterly force survey: Quarter 3 2009. [Online] Available:

http://www.statsa.gov.za. (Accessed 15 December 2009)

Steyn, H.S. (2000). Practical significance of the difference in means. South African Journal of Industrial Psychology, 26(3), pp. 1-3.

Sun, Y. \& Stynes, D.J. (2006). A note on estimating visitor spending on a per-day/night basis. Tourism Management, 27, pp. 721-725.

Taylor, D.T., Fletcher, R.R. \& Clabaugh, T. (1993). A comparison of characteristics, regional expenditures, and economic impact of visitors to historical sites and other recreational visitors. Journal of Travel Research, 32(5), pp. 30-35.

Thrane, C. (2002). Jazz festival visitors and their expenditures: Linking spending patterns to musical interest. Journal of Travel Research, 40, pp. 281-286.

Tonge, J. \& Moore, S.A. (2007). Importance-satisfaction analysis for marine park hinterlands: A Western Australia case study. Tourism Management, 28(3), pp. 768-776.

Uysal, M., McDonald, C.D. \& Martin, B.S. (1994). Australian visitors to US national parks and natural areas. International Journal of Contemporary Hospitality Management, 6(3), pp. 18-24.

Wade, D.J. \& Eagles, P. (2003). The use of importance-performance analysis and market segmentation for tourism management in parks and protected areas: An application in Tanzania's national parks. Journal of Ecotourism, 2(3), pp. 196-212.

World Tourism Organisation - see WTO

WTO. (2002). Enhancing the Economic Benefits of Tourism for Local Communities and Poverty Alleviation. World Tourism Organisation, Geneva, Switzerland. 